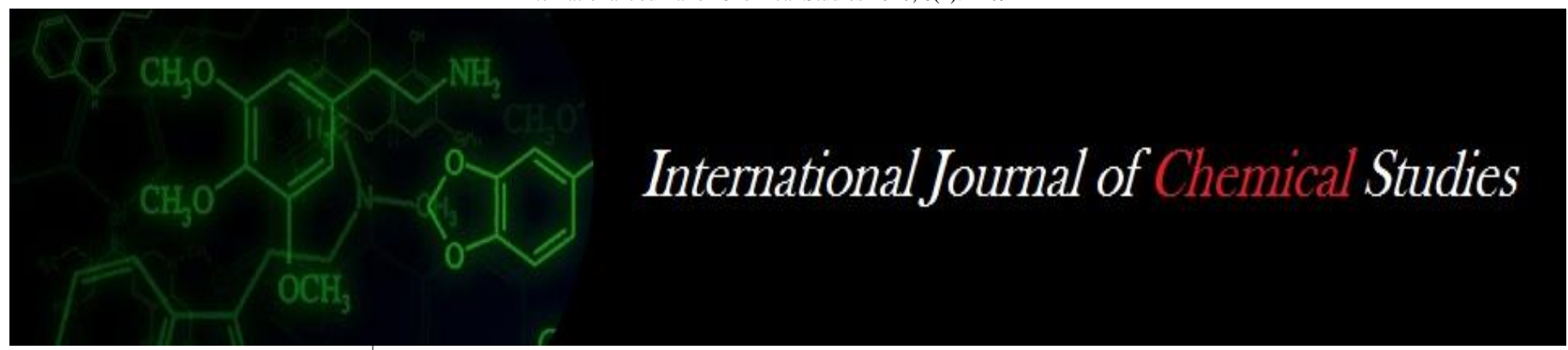

P-ISSN: 2349-8528

E-ISSN: 2321-4902

www.chemijournal.com

IJCS 2020; 8(2): 2109-2111

(C) 2020 IJCS

Received: 06-01-2020

Accepted: 07-02-2020

\section{Padmakshi Thaku}

Department of Vegetable

Science, CoA; IGKVV, Raipur,

Chhattisgarh, India

\section{J Singh}

Department of Vegetable

Science, CoA; IGKVV, Raipur,

Chhattisgarh, India

\section{J Trivedi}

Department of Vegetable

Science, CoA; IGKVV, Raipur,

Chhattisgarh, India

\section{SK Nair}

Department of Genetics and

Plant Breeding, CoA; IGKVV,

Raipur, Chhattisgarh, India
Corresponding Author: Padmakshi Thakur

Department of Vegetable

Science, CoA; IGKVV, Raipur,

Chhattisgarh, India

\section{Estimation of genetic divergence in Bottle gourd [Lagenaria siceraria (Mol.) Standl.] for yield and it's attributing traits}

\author{
Padmakshi Thakur, J Singh, J Trivedi and SK Nair
}

DOI: $\underline{\text { https://doi.org/10.22271/chemi.2020.v8.i2af.9062 }}$

\begin{abstract}
The genetic divergence among 73 genotypes of bottle gourd [Lagenaria siceraria (Mol.) Standl.] was determined through Cluster analysis and Mohalanobis's $\mathrm{D}^{2}$ analysis. The cluster analysis grouped all 73 bottle gourd genotypes into 6 major clusters based on $\mathrm{D}^{2}$ value. Extreme genetic divergence was estimated among clusters. Maximum number of genotypes were grouped into cluster III included 22 genotypes. Maximum inter cluster distance was found between cluster I and cluster VI (9.347) which would be fruitful for developing heterotic cross combination. The maximum intra cluster distance was observed in cluster VI (2.865) closely followed by cluster IV (2.436) indicating maximum diversity within these clusters. Cluster I showed highest mean value for no. of fruits per plant, yield $(q / h a)$ and expressed lowest mean performance for node number at which first male flower appears, node number at which first female flower appears, days to first female flower appears, days to $50 \%$ flowering, days to fruit set, days to first fruit harvest and duration of crop.
\end{abstract}

Keywords: Bottle gourd, cluster, divergence, genotypes and yield

\section{Introduction}

Bottle gourd [Lagenaria siceraria (Mol.) Standl.] is one of the most popular vegetable of the family Cucurbitaceae, with a diploid chromosome number, $2 \mathrm{n}=22$. It is a fast growing climbing annual, native to Africa. It is grown in both rainy and summer season and its fruits are available in the market throughout the year. Bottle gourd is a rich source of minerals and vitamins. In Chhattisgarh, no comprehensive systematic research has been done in this crop. A large number of local lines are cultivated in this region but there is no recommended cultivar. In crop improvement programme, genetic diversity has been considered as an important factor which is also essential pre-requisite for hybridization programme for obtained progenies with important desirable characters like disease resistance, earliness, quality or even performance of a particular character for the yield improvement and future utilization of local germplasm. Such study also selects the genetically divergent parents to obtain desirable combinations in the segregating generations. Information on nature and degree of genetic divergence would help the plant breeder in choosing the right parents for the breeding programme. Being cross pollinated crop, due to monoecy there is a ample scope for exploitation of heterosis in it. Genetically diverse parents are likely to segregate and produce high heterotic crosses. More diverse the parents, greater are the chances of obtaining high heterotic $\mathrm{F}_{1}$ 's and broad spectrum of variability in segregating generations (Arunachalam, 1981) ${ }^{[2]}$. Keeping this in view, the present study was focused to assess the genetic diversity of 73 promising bottle gourd genotypes using Mahalanobis $\mathrm{D}^{2}$ statistics.

\section{Materials and methods}

The study was carried out during kharif season (2015-16) at Research cum Instructional farm at Department of Vegetable Science, IGKV, Raipur. The experiment comprised of 73 genotypes of bottle gourd laid out in a Randomized Block Design with three replications at 3.0 $\times 0.75 \mathrm{~m}$ row to row and plant to plant spacing. All the recommended cultural practices were adopted to raise a healthy crop. Data were recorded on five randomly selected plants with respect to characters viz., days to first male flower appear, days to first female flower appear, node number at which first male appear, node number at which first female flower appear, 
days to $50 \%$ flowering, days to fruit set, number of branches per plant, days to first fruit harvest, fruit length $(\mathrm{cm})$, average fruit weight $(\mathrm{g})$, fruit girth $(\mathrm{cm})$, number of fruits per plant, fruit yield (q/ha) and crop duration. The genetic divergence was estimated using Mahalanobis $D^{2}$ method (1936) and the populations were grouped into different clusters treating $\mathrm{D}^{2}$ as the square of generalized distance, following Tocher's method as described by Rao (1952) ${ }^{[8]}$.

\section{Results and discussion}

The analysis of variance revealed significant differences among bottle gourd genotypes for all characters suggesting considerable genetic variability in the population. Using the estimated $\mathrm{D}^{2}$ values as squares of generalized distance, 73 genotypes were grouped into 6 clusters (Table 1). Maximum number of genotypes were grouped into cluster III which included 22 genotypes which is followed by cluster II having 17 genotypes, cluster IV included 12 genotypes, cluster V had 11 genotypes. Cluster VI consisted 7 genotypes and cluster I having 4 genotypes. From the clustering pattern, it was found that the genotypes from different regions were independent of their genetic origin. Hence the genotypes studied were reliable enough for hybridization and selection. Similar findings are also reported by Bhardwaj et al. (2013) ${ }^{[3]}$, Ara et al. (2014) ${ }^{[1]}$ and Visen et al. (2015) ${ }^{[12]}$ who reported that all genotypes differed significantly for almost all the characters and were grouped into clusters based on the similarities of $\mathrm{D}^{2}$ value and there was no parallelism between the clustering pattern and geographic origin.

The average inter and intra cluster distances among the six clusters are presented in Table 2. Maximum inter cluster distance was observed between cluster I and VI (9.347) followed by cluster I and IV (7.949), cluster I and III (7.636), cluster I and V (7.018), cluster II and VI (6.559), cluster II and IV (5.468). The rest of the combinations for inter cluster distance varied from 5.315 to 2.571 with least distance cluster III and V (2.571). The higher inter-cluster distance indicated greater genetic divergence between the genotypes of those clusters, while lower inter-cluster values between the clusters suggested that the genotypes of the clusters were not much genetically diverse from each other. The maximum intra cluster distance was observed in cluster VI (2.865) closely followed by cluster IV (2.436) indicating maximum diversity within these clusters. Genotypes from distant clusters could be exploited in hybrid development programmes due to their wide genetic distance. These results are in general agreement with the findings of Islam (2004) ${ }^{[4]}$, Singh et al. (2007) ${ }^{[10]}$ and Bhardwaj et al. (2013) ${ }^{[3]}$ and Thakur et al. (2015) ${ }^{[11]}$ who reported that genotypes from higher inter cluster distance would be fruitful for developing heterotic cross combination. The mean performance for different clusters of genotypes for yield and its components are presented in Table 3. Cluster I showed highest mean value for no. of fruits per plant, yield (q/ha) and expressed lowest mean performance for node number at which first male flower appears, node number at which first female flower appears, days to first female flower appears, days to $50 \%$ flowering, days to fruit set, days to first fruit harvest and duration of crop while cluster II showed lowest mean value for days to first male flower appears. Cluster IV showed highest mean performance for fruit girth and average fruit weight. Cluster $\mathrm{V}$ exhibited high mean value for no. of branches per plant. Cluster VI expressed highest mean value for fruit length. Similar results were also reported by Thakur et al. (2015) ${ }^{[11]}$ and Visen et al. (2015) ${ }^{[12]}$ who reported that cluster mean for various traits showed that different cluster respond differentially for various traits.

The contribution of each character to divergence is presented in Table 4 which showed node number at which first female flower appears contributes highest (32\%) to divergence followed by node number at which first male flower appears (21.69\%), days to $50 \%$ flowering (21.04\%), number of branches per plant $(11.71 \%)$ Whereas, average fruit weight $(4.33 \%)$, days to first male flower $(3.88 \%)$, days to first female flower $(1.36 \%)$, days to first fruit harvest $(0.87 \%)$, yield quintal per ha $(0.87 \%)$, duration of crop $(0.83 \%)$, fruit length $(0.64 \%)$, days to fruit set $(0.49 \%)$ number of fruits per plant $(0.15 \%)$ and fruit girth $(0.07 \%)$ contribute lowest to divergence. This contribution is an important consideration for the purpose of further selection and choice of parents for hybridization. The results of the present study was close agreement with findings of Islam (2004) ${ }^{[4]}$ who reported that primary branches per plant, fruit length and weight, number of fruits and yield per plant contributed the most of the total genetic divergence and Mladenovic et al. (2012) ${ }^{[6]}$ in bottle gourd. Similar findings were also reported by Kundu et al. (2012) ${ }^{[7]}$ and Singh et al. (2013) ${ }^{[9]}$ in bitter gourd.

The present study revealed that in terms of inter cluster distance and characters with high $\mathrm{D}^{2}$ values, there is a scope for varietal improvement through hybridization programme involving the selected genotypes under cluster I and cluster VI because higher inter-cluster distance would help in achieving novel recombinants. Thus, while planning hybridization programme for the development of heterotic hybrids and better transgressive segregants one should select genotypes from cluster I for lower male and female node, early female flower appears, days to $50 \%$ flowering, days to fruit set, days to first fruit harvest, fruit length and yield quintal per hectare. Similarly genotypes from cluster II for days to first male flower appears whereas, genotypes from cluster III for fruit weight and genotypes from cluster IV for fruit girth and number of branches and genotypes from VI higher number of fruits per plant. Genetic divergence is one of the useful tools for selection and efficient use of parents for hybridization to develop high yielding potential cultivars/ hybrids. Inclusion of more diverse parents in hybridization is believed to increase the chances of obtaining stronger heterosis and gives broad spectrum of variability in segregating generations.

Table 1: Composition of clusters in bottle gourd genotypes

\begin{tabular}{|c|c|c|}
\hline $\begin{array}{c}\text { Cluster } \\
\text { Number }\end{array}$ & $\begin{array}{c}\text { Number of genotypes } \\
\text { included }\end{array}$ & Name of genotypes \\
\hline I & 4 & Pusa Naveen, Pusa Samrudhi, Arka Bahar, NBBL-15 \\
\hline II & 17 & $\begin{array}{r}\text { IBG-3, IBG-4, IBG-10, IBG-19, IBG-36, IBG-37, IBG-38, IBG-42, IBG-43, IBG-44, IBG-45, IBG-46, IBG-50, IBG- } \\
57, \text { IBG-60, IBG-62, IBG-66 }\end{array}$ \\
\hline III & 22 & $\begin{array}{r}\text { IBG-2, IBG-11, IBG-12, IBG-13, IBG-14, IBG-16, IBG-17, IBG-18, IBG-20, IBG-23, IBG-24, IBG-25, IBG-26, IBG- } \\
\text { 27, IBG-29, IBG-32, IBG-33, IBG-40, IBG-48, IBG-49, IBG-51, IBG-53 }\end{array}$ \\
\hline IV & 12 & IBG-Local, IBG-28, IBG-31, IBG-34, IBG-41, IBG-56, IBG-59, IBG-61, IBG-63, IBG-64, IBG-65, IBG-68 \\
\hline V & 11 & IBG-5, IBG-6, IBG-7, IBG-8, IBG-9, IBG-15, IBG-22, IBG-30, IBG-39, IBG-52, IBG-54 \\
\hline VI & 7 & IBG-21, IBG-35, IBG-47, IBG-55, IBG-58, IBG-67, IBG-69 \\
\hline
\end{tabular}


Table 2: Intra (bold) and Inter cluster distance values in clusters formed of bottle gourd genotypes

\begin{tabular}{|c|c|c|c|c|c|c|}
\hline Cluster Number & I & II & III & IV & V & VI \\
\hline I & 1.003 & & & & & \\
\hline II & 5.315 & 2.328 & & & & \\
\hline III & 7.636 & 3.695 & 2.300 & & & \\
\hline IV & 7.949 & 5.468 & 3.878 & 2.436 & & \\
\hline V & 7.018 & 3.494 & 2.571 & 2.759 & 2.288 & \\
\hline VI & 9.347 & 6.559 & 3.812 & 3.213 & 4.397 & 2.865 \\
\hline
\end{tabular}

Table 3: Mean performance of genotypes in individual cluster for yield and its components

\begin{tabular}{|c|c|c|c|c|c|c|c|c|c|c|c|c|c|c|c|}
\hline \multicolumn{2}{|c|}{ Character/Cluster } & \multirow[t]{2}{*}{\begin{tabular}{|c|}
$\begin{array}{c}\text { Node no. } \\
\text { at which } \\
1^{\text {st }} \text { male } \\
\text { flower } \\
\text { appears }\end{array}$ \\
3.52
\end{tabular}} & \multirow[t]{2}{*}{$\begin{array}{c}\text { Node no. } \\
\text { at which } \\
\mathbf{1}^{\text {st }} \text { female } \\
\text { flower } \\
\text { appears } \\
4.97\end{array}$} & \multirow[t]{2}{*}{$\begin{array}{c}\begin{array}{c}\text { Days to } \\
1^{\text {st }} \text { male } \\
\text { flower } \\
\text { appears }\end{array} \\
23.42 \\
\end{array}$} & \multirow[t]{2}{*}{\begin{tabular}{|c}
$\begin{array}{c}\text { Days to } \\
1^{\text {st }} \\
\text { female } \\
\text { flower } \\
\text { appears }\end{array}$ \\
27.2
\end{tabular}} & \multirow[t]{2}{*}{\begin{tabular}{|c|}
$\begin{array}{c}\text { Days to } \\
\mathbf{5 0 \%} \\
\text { flowering }\end{array}$ \\
26.92
\end{tabular}} & \multirow[t]{2}{*}{\begin{tabular}{|c|}
$\begin{array}{c}\text { Days } \\
\text { to } \\
\text { fruit } \\
\text { set }\end{array}$ \\
32.53 \\
\end{tabular}} & \multirow[t]{2}{*}{\begin{tabular}{|l|}
$\begin{array}{l}\text { Days to } \\
\mathbf{1}^{\text {st }} \text { fruit } \\
\text { harvest }\end{array}$ \\
43.16 \\
\end{tabular}} & \multirow[t]{2}{*}{\begin{tabular}{|c|}
$\begin{array}{r}\text { Fruit } \\
\text { length } \\
(\mathbf{c m})\end{array}$ \\
32.16 \\
\end{tabular}} & \multirow[t]{2}{*}{\begin{tabular}{|l|}
$\begin{array}{l}\text { Fruit } \\
\text { girth } \\
(\mathbf{c m})\end{array}$ \\
28.92 \\
\end{tabular}} & \multirow[t]{2}{*}{$\begin{array}{c}\begin{array}{c}\text { Avg. } \\
\text { fruit } \\
\text { weight } \\
(\mathbf{g})\end{array} \\
1004 \\
\end{array}$} & \multirow[t]{2}{*}{\begin{tabular}{|c|}
$\begin{array}{c}\text { No. of } \\
\text { fruits } \\
\text { per } \\
\text { plant }\end{array}$ \\
13.12 \\
\end{tabular}} & \multirow[t]{2}{*}{\begin{tabular}{|c}
$\begin{array}{c}\text { No. of } \\
\text { branches } \\
\text { per plant }\end{array}$ \\
3.54 \\
\end{tabular}} & \multirow[t]{2}{*}{\begin{tabular}{|c}
$\begin{array}{c}\text { Duration } \\
\text { of crop } \\
\text { (sowing to } \\
\text { last } \\
\text { harvest) }\end{array}$ \\
127.83 \\
\end{tabular}} & \multirow{2}{*}{\begin{tabular}{|l|} 
Yield \\
(q/ha)
\end{tabular}} \\
\hline I & 4 & & & & & & & & & & & & & & \\
\hline II & 22 & 12.24 & 17.46 & \begin{tabular}{|l|}
23.1 \\
\end{tabular} & 30.82 & 29.08 & 35.97 & 47.63 & 30.11 & 28.32 & 869.72 & \begin{tabular}{|l|}
8.82 \\
\end{tabular} & 4.57 & 157.71 & 198.44 \\
\hline III & 17 & & 26.26 & & & & 45.64 & & 27.56 & 31.1 & 684.78 & 1 & & & 168.7 \\
\hline IV & 12 & 23.2 & 32 & 35.9 & 43.28 & 42.72 & 48.98 & 60.42 & 25.99 & 36.72 & 1157.16 & 10.61 & 5.6 & 153.97 & 243.13 \\
\hline $\mathrm{V}$ & 11 & 17.08 & 25.31 & 30.98 & 38.7 & 36.61 & 43.58 & 54.95 & 24.3 & 36.46 & 926.65 & 9.24 & 6.7 & 156.55 & 198.73 \\
\hline VI & 7 & 23.34 & 29.3 & 43.44 & 49.08 & 49.86 & 54.12 & 64.86 & 34.66 & 32.4 & 871.1 & 8.99 & 5 & 155.62 & 201.05 \\
\hline
\end{tabular}

Table 4: Contribution of each character to divergence

\begin{tabular}{|c|c|c|c|}
\hline S. No. & Characters & Number of times appearing first rank & Per cent contribution \\
\hline 01 & Node no. at which $1^{\text {st }}$ male flower appears & 570 & 21.69 \\
\hline 02 & Node no. at which $1^{\text {st }}$ female flower appears & 841 & 32.00 \\
\hline 03 & Days to $1^{\text {st }}$ male flower appears & 102 & 3.88 \\
\hline 04 & Days to $1^{\text {st }}$ female flower appears & 36 & 1.36 \\
\hline 05 & Days to $50 \%$ flowering & 553 & 21.04 \\
\hline 06 & Days to fruit set & 13 & 0.49 \\
\hline 07 & Days to $1^{\text {st }}$ fruit harvest & 23 & 0.87 \\
\hline 08 & Fruit length $(\mathrm{cm})$ & 17 & 0.64 \\
\hline 09 & Fruit girth $(\mathrm{cm})$ & 2 & 0.07 \\
\hline 10 & Average fruit weight (gm) & 114 & 4.33 \\
\hline 11 & No. of fruits per plant & 4 & 0.15 \\
\hline 12 & No. of branches per plant & 308 & 11.71 \\
\hline 13 & Duration of crop (sowing to last harvest) & 22 & 0.83 \\
\hline 14 & Yield (q/ha) & 23 & 0.87 \\
\hline & Total & 2628 & 100 \\
\hline
\end{tabular}

\section{References}

1. Ara ZG, Zakaria M, Uddin MZ, Rahman MM, Rasul MG, Kabir AFMR. Genetic divergence in bottle gourd. International Journal of Natural and Social Sciences. $2014 ; 1: 20-25$.

2. Arunachalam V. Genetic distances in plant breeding. Indian J Genet. 1981; 41:226-236.

3. Bhardwaj DR, Singh A, Singh U. Genetic variability of bottle gourd [Lagenaria siceraria (mol.) Standl.] by multivariate analysis. Published in Proc. of National Symposium on Abiotic and Biotic Stress management in Vegetable Crops. Ind. Soc. Veg. Sci, 2013, 370p.

4. Islam MT. Genetic divergence in bottle gourd [Lagenaria siceraria (mol.) Standl.]. Bulletin of the Institute of Tropical Agriculture, Kyushu University. 2004; 27:1924.

5. Mahalanobis PC. On the generalized distance in statistics. Proc. Nat. Inst. Sci., India. 1936; 21:49-55.

6. Mladenovic E, Berenji J, Ognjanov V, Ljubojevic M, Cukanovic J. Genetic variability of bottle gourd (Lagenaria siceraria (mol.)) standley and its morphological characterization by multivariate analysis. Arch. Biol. Sci., Belgrade. 2012; 64(2):573-583.

7. Kundu BC, Hossain MM, Khaleque Mian MA, Mian IH. Genetic divergence in bitter gourd (Momordica charntia L.). J Asiat. Soc. Bangladesh, Sci. 2012; 38(2):125-134.
8. Rao CR. Advance Statistical Methods in Biometrics Research. Hofaer Pub. Darion, 1952, 371-378.

9. Singh B, Singh AK, Kumar S. Genetic divergence studies in bitter gourd (Momordica charantia L.). Acad. J of Plant Sci. 2013; 6(2):89-91.

10. Singh KP, Singh VK, Saha BC. Genetic divergence in bottle gourd. J of Interacademicia. 2007; 11(1):28-33.

11. Thakur P, Sharma D, Dash SP, Nair SK. Genetic divergence in bottle gourd [Lagenaria siceraria (mol.) Standl. ]. J of Environ. Biosci. 2015; 29(2):555-558

12. Visen VK, Thakur P, Sharma D, Nair SK. Genetic divergence studies in bottle gourd [Lagenaria siceraria (mol.) Standl.]. Plant Archives. 2015; 15(2):1175-1178. 